\title{
The Effect of Dividend Payout Ratio, Net Profit Margin, and Return on Assets on The Growth of Income (Case Study On Coal Mining Sector Companies Registered in Indonesia Stock Exchange Period 2017-2019)
}

\author{
Sigit Prabowo
}

Department of Management, Faculty of Economics and Business, Narotama University, Surabaya, Indonesia

\begin{abstract}
The aim of this study was to determine whether there was an influence between DPR, NPM, and ROA on company profit growth. The population used is coal mining companies listed on the Indonesia Stock Exchange, consisting of 17 companies with 3 periods, namely 2017-2019. The sampling technique is done by means of saturated samples or census samples, in which the entire population is used as the sample. The data in this study are secondary data. Data analysis used multiple linear regression using SPSS. Tests were carried out using a significance level of 0.05 . The results of the partial DPR research show a regression coefficient of 0.073 (positive) with a sig value (0.999), meaning that it has a positive and insignificant effect on profit growth. The results of the research in partial NPM show a regression coefficient of 447.313 (positive) with a sig value $(0.000)$ which means that it has a significant positive effect on profit growth and the results of the research in partially ROA show a regression coefficient of 340.076 (positive) with a sig value (0.007) which means that it has a significant positive effect on profit growth.
\end{abstract}

Keywords: Dividend Payout Ratio (DPR), Net Profit Margin (NPM), Return On Assets (ROA) and profit growth.

\section{Introduction}

Coal is an organic rock that is formed from fossil plants, is dark in color and contains minerals that are classified as non-biological natural resources, namely a source that can be reproduced and can be used continuously. Mining in the coal sector requires enormous costs. For this reason, many companies enter the capital market to absorb funds from investors. Company policies funding have an important role in increasing company profits. In 2019 the number of coal sub-sector mining companies listed on the IDX reached 24 companies, of the total companies there were 17 companies that routinely reported financial reports in the period 2017-2019.

The Dividend Payout Ratio policy within the company has an important impact on the many parties involved in it. Dividend policy is a policy that is carried out at a cost that is quite expensive, because companies must provide large amounts of funds for dividend payments (Farrukh, et.al., 2017; Herlambang, Murhadi, \& Susanto, 2018). For shareholders or investors, dividends are the rate of return on their investment in the form of share ownership issued by other companies.

For the company management, this dividend distribution will later reduce the cash held by the company so that this causes the company to invest less. As for creditors, the dividend distribution is a positive signal to see the company's ability to pay interest and pay off loan principal. Generally, investors invest in a company with the aim of expecting returns in the form of dividends and capital gains to increase their welfare. On the one hand, the company also wants growth that continues to increase in order to sustain its life and provide greater welfare to shareholders.

\footnotetext{
* Corresponding author.

E-mail address: sigiprab94@gmail.com (Sigit Prabowo)
} 
ROA can be used to measure the net profit obtained from the use of assets (Irman \& Purwati, 2020; Juwita, et.al., 2018). The higher the ROA value in each period, the greater the company's profit growth rate. The most important part of the company is good management of financial performance, so that company profits will consistently increase. Financial statements are a basis for information in making decisions. Decisions made by company managers are the result of the company's evaluation of generating profits. Then the financial reports need to be analyzed so that they can be useful for the parties concerned. One way to analyze financial statements is to use financial ratios.

\section{Literature Review}

\subsection{Profit Growth}

Profit growth is the increase in the percentage of profit or revenue that the company earns. Net income (profit) is often used as a measure of performance or the basis for other measures such as gimbal returns on investment (returns on investment) or earnings per share (earnings per share). In general, the performance appraisal of a company is seen from profit growth, the better the percentage value of profit growth, the better the company's performance, including the company's manager's performance.

According to Harahap (2018), profit growth is calculated by subtracting this year's net profit from last year's net profit then dividing last year's net profit.

\subsection{Dividend Payout Ratio}

Dividend payout ratio is a financial ratio that measures the percentage level of net income distributed to each shareholder (investor) in the form of dividends made in one period or once a year (Abiahu \& Amahalu, 2017). The dividend payout ratio is very important for investors, those (investors) who want profits in the short term will prefer to invest in companies that have a high dividend payout ratio, whereas if they (investors) want capital growth they will invest in companies with dividend payouts. the ratio is low.

\subsection{Net Profit Margin}

Net profit margin is a financial ratio used to measure the percentage of net income or the level of profit in a company on net sales (Mulyadi \& Sihabudin, 2020). The definition of net profit margin is also expressed by experts such as according to Kasmir (2008), net profit margin is a measure of profit that generally compares company income after interest and taxes with sales, NPM can also compare with the industry average of a company. The higher the value of a company's net profit margin, the thicker the company's profit and the more efficient its operations are. The company is able to reduce the unnecessary costs so that it can maximize the net profit it gets.

\subsection{Return On Asset}

Return on Asset is a financial ratio that is used to measure the level of a company's ability to generate profits from the assets used which will then be projected into the future or future periods (Purba \& Bimantara, 2020). Company assets are total assets obtained from own capital or from foreign capital such as investors, which are used for the continuity of company operations which are converted into company assets. 


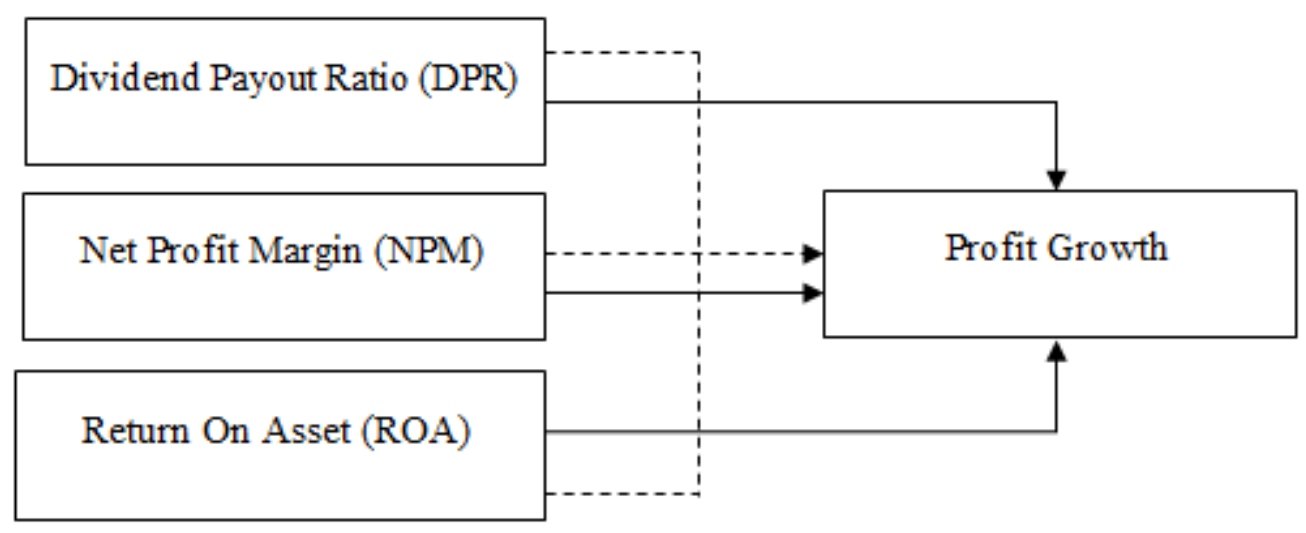

Fig. 1 Conceptual Framework

\section{Methods}

This study uses an associative approach because it wants to explain the relationship between the independent variable and the dependent variable. Namely used to explain the effect of Dividend Payout Ratio, Net Profit Margin, and Return On Asset on profit growth of coal mining companies listed on the Indonesia Stock Exchange.

\section{Result and Discussions}

\subsection{Descriptive Analysis}

Table 1. Result of Descriptive Analysis

\begin{tabular}{crrrrr}
\hline Variable & N & Minimum & Maximum & \multicolumn{1}{c}{ Mean } & \multicolumn{1}{c}{ Std. Deviation } \\
\hline Profit Growth & 51 & -458.39 & 2278.23 & 98.4708 & 404.54908 \\
DPR & 51 & 0.04 & 3.54 & 1.2298 & 0.78277 \\
NPM & 51 & -0.09 & 2.88 & 0.6275 & 0.61857 \\
ROA & 51 & 0.01 & 2.18 & 0.3636 & 0.47989 \\
\hline
\end{tabular}

Based on table 1, it can see that:

1. Profit Growth

It is known that the minimum profit growth is -458.39 and the maximum is 2278.23 . The average value is 98.4708 with a standard deviation of 404.54908 . The company with the highest profit growth value was Darma Henwa Tbk in 2018, namely 2278.23, and the company with the lowest growth was Alfa Energy Investama Tbk in 2019 which was -458.39 .

2. Divident Payout Ratio

It is known that the minimum Dividend Payout Ratio is -0.28 and the maximum is 19.60 . The average value is 2.0015 with a standard deviation of 3.58811 . The company with the highest dividend payout ratio was Indika Energy Tbk in 2019, namely 19.60, and the company with the lowest Dividend Payout Ratio was Alfa Energy Investama Tbk in 2019, namely -0.28.

3. Net Profit Margin

It is known that the minimum Net Profit Margin is -0.09 and the maximum is 1.54 . The average value is 0.1206 with a standard deviation of 0.21761. The company with the highest Net Profit Margin value was 
Alfa Energy Investama Tbk in 2017, namely 1.54, and the company with the lowest Net Profit Margin value was Atlas Resources Tbk in 2019 which was -0.09 .

\section{Return On Asset}

It is known that the minimum return on assets is -1.52 and the maximum is 18.33 . The average value is 2.5901 with a standard deviation of 4.41004. The company with the highest Return On Asset value was Bayan Resoiurces Tbk in 2019, namely 18.33, and the company with the lowest Return On Asset value was Atlas Resources Tbk in 2019, namely -1.52 .

\subsection{Data Normality test}

Table 2. Kolmogorov Smirnov test

\begin{tabular}{ccc}
\hline One Sample & $\begin{array}{c}\text { Unstandardized } \\
\text { Residual }\end{array}$ & Information \\
\hline $\begin{array}{c}\text { Kolmogorov_Smirnov Z } \\
\text { Asymp.Sig (2-tailed) }\end{array}$ & 0.095 & Normal \\
\hline
\end{tabular}

Based on table 2, the Kolmogorov Smirnov test, it can be seen that the data in this study are normally distributed. Value of Asymp. Sig (2-tailed) of 0.095 indicates a significant value greater than 0.05 , which means that the data in this study are normally distributed.

\subsection{Multiple Linear Regression Test}

Multiple linear regression analysis aims to see the effect between the independent variable and the dependent variable which shows a one-way relationship. The following is a table of results from multiple linear regression analysis.

Table 3. Multiple Linear Regression Test

\begin{tabular}{cc}
\hline Model & Unstandardized Coefficients \\
& B \\
\hline (Constant) & -305.800 \\
DPR & 0.073 \\
NPM & 447.313 \\
ROA & 340.076 \\
\hline
\end{tabular}

Based on table 3, the linear regression equation can be obtained as follows:

$$
\mathrm{Y}=-305.800+0.073 \mathrm{X} 1+447.313 \mathrm{X} 2+340.076 \mathrm{X} 3
$$

Based on the multiple linear equation, it can be described as follows:

1. The regression coefficient value of the DPR variable $(\beta 1)$ is 0.073 , which means that if the DPR is increased by one unit, assuming the variable NPM and ROA are considered constant, it will increase profits by 0.073 .

2. The regression coefficient value of the NPM variable $(\beta 2)$ is 447.313 , meaning that if the NPM is increased by one unit, assuming the variable DPR and ROA are considered constant, it will increase the profit by 447.313

3. The regression coefficient value of the ROA variable $(\beta 3)$ is 340.076 , meaning that if the ROA is increased by one unit, assuming the DPR variable and NPM are considered constant, it will increase the profit by 340.076 . 
The $t$ test aims to test how the influence of each independent variable individually on the dependent variable. In this study, testing was carried out to test the DPR, NPM, and ROA variables on profit growth. Tests were carried out using a significance level of $0.05(5 \%)$ with a one-way hypothesis. This research can be seen in the following table:

Table 4. T test (Partial test)

\begin{tabular}{crrrc}
\hline Model & \multicolumn{1}{c}{$\mathrm{B}$} & \multicolumn{1}{c}{$\mathrm{t}$} & \multicolumn{1}{c}{ Sig } & Information \\
\hline (Constant) & -305.800 & 1.653 & 0.105 & \\
DPR & 0.073 & -0.001 & 0.999 & Not significant \\
NPM & 447.313 & 3.861 & $<0.001$ & Significant \\
ROA & 340.076 & 2.838 & 0.007 & Significant \\
\hline
\end{tabular}

The results of the $t$ test on the DPR variable (X1), the regression coefficient of 0.073 (positive), with $t$ count $(-0.001)$ and sig (0.999). When compared with $t$ table (2.00958), then $t$ count $<t$ table and sig $>0.05$. With the assumption that other variables are considered constant, it can be concluded that the Dividend Payout Ratio has a positive but insignificant effect on profit growth. Based on this analysis, it can be concluded that the first hypothesis which states that the Dividend Payout Ratio has a significant positive effect on profit growth is rejected.

The $t$ test results on the NPM variable (X2), the regression coefficient of 447.313 (positive), with $t$ count (3.861) and sig < 0.001. When compared with $t$ table (2.00958), then $t$ count $>t$ table and sig <0.05. With the assumption that other variables are considered constant, it can be concluded that Net Profit Margin has a significant positive effect on profit growth. Based on this analysis, it can be concluded that the second hypothesis which states that Net Profit Margin has a significant positive effect on profit growth is received.

The results of the $t$ test on the ROA variable (X3), the regression coefficient of 340.076 (positive), with $t$ count (2.838) and sig (0.007). When compared with t table (2.00958), then $t$ count $>t$ table and sig <0.05. With the assumption that other variables are considered constant, it can be concluded that Return on Assets has a significant positive effect on earnings growth. Based on this analysis, it can be concluded that the third hypothesis which states that Return on Assets has a significant positive effect on profit growth is accepted.

The test aims to test how the effect of all the independent variables simultaneously (together) on the dependent variable. In this study, testing was carried out to test the DPR, NPM, and ROA variables on profit growth. Tests were carried out using a significance level of $0.05(5 \%)$ with a one-way hypothesis. This research can be seen in the following table:

Table 5. F Test (Simultaneous Test)

\begin{tabular}{ccc}
\hline $\mathrm{F}$ & $\mathrm{Sig}$ & Information \\
\hline 8.572 & $<0.001$ & Significant \\
\hline
\end{tabular}

The $f$ test results show that $f$ count $(8,572)$ and sig $(0,000)$. When compared with $f(2.80)$, then $f$ count $>f$ table and sig $<0.05$, so it can be concluded that the model is significant. Based on this analysis, it can be concluded that the fourth hypothesis states that Divident Payout Ratio, Net Profit Margin and Return On Asset has a significant positive effect on received profit growth.

Table 6. Test of the coefficient of determination

\begin{tabular}{cc}
\hline R Square & Information \\
\hline 0.354 & Weak \\
\hline
\end{tabular}


The result of the coefficient of determination test shows that the value of R Square is 0.354 or $35.4 \%$. This means that the rate of profit growth that can be explained by the independent variables (DPR, NPM, and ROA) is 35.4\%, while the remaining $64.6 \%$ is influenced by other variables not examined in this study.

\section{Conclusions}

Based on the result and discussion, we can conclude that:

1) The results of the research partially show that the Divident Payout Ratio (X1) Has a positive and insignificant effect on Profit Growth (Y), this can be proven by t count $(-0.001)<\mathrm{t}$ table $(2.00958)$ and sig $(0.999)>(0.05)$. This means that the high value of the Divident Payout Ratio will not be followed by an increase in profit growth in coal mining companies for the 2017-2019 period listed on the Indonesia Stock Exchange.

2) The results of this research partially show that the Net Profit Margin (X2) has a significant positive effect on Profit Growth (Y), this can be proven by t count $(3.861)>t$ table $(2.00958)$ and sig $(0.001)<(0.05)$. This means that the high Net Profit Margin value will be followed by an increase in profit growth in coal mining companies for the 2017-2019 period listed on the Indonesia Stock Exchange.

3) The results of the research partially show that Return On Asset (X3) has a positive and insignificant effect on Profit Growth (Y), this can be proven by t count $(2.838)>t$ table $(2.00958)$ and sig $(0.007)<(0,05)$. This means that the high value of Return On Assets will be followed by an increase in profit growth in coal mining companies for the period 2017-2019 which are listed on the Indonesia Stock Exchange.

\section{References}

Abiahu, M. F. C., \& Amahalu, N. (2017). Effect of taxation on dividend policy of quoted deposit money banks in Nigeria (2006-2015). Abiahu, MC \& Amahalu, NN (2017). Effect of taxation on dividend policy of quoted deposit money banks in Nigeria (2006-2015). EPH-International Journal of Business \& Management Science, 2(3), 1-30.

Farrukh, K., Irshad, S., Khakwani, M. S., Ishaque, S., \& Ansari, N. Y. (2017). Impact of dividend policy on shareholders wealth and firm performance in Pakistan. Cogent Business \& Management, 4(1), 1408208.

Harahap, S. S. (2006). Analisa Kritis Atas Laporan Keuangan, Jakarta, PT. Raya Grafindo Persada.

Herlambang, A., Murhadi, W. R., \& Susanto, G. A. (2018, March). The effect of corporate governance on the capital structure of non-financial companies in the period of 2011-2015. In 15th International Symposium on Management (INSYMA 2018). Atlantis Press.

Irman, M., \& Purwati, A. A. (2020). Analysis On The Influence Of Current Ratio, Debt to Equity Ratio and Total Asset Turnover Toward Return On Assets On The Otomotive and Component Company That Has Been Registered In Indonesia Stock Exchange Within 2011-2017. International Journal of Economics Development Research (IJEDR), l(1), 36-44.

Juwita, S., Raga, P. D. J., Prasetyo, F. I., \& Rimawan, E. (2018). Effect of CAR (Capital Adequacy Ratio), BOPO (Operational Costs on Operational Revenues) and LDR (Loan to Deposit Ratio) to ROA (Return on Assets) PD Bank Pasar Bogor City. International Journal of Innovative Science and Research Technology, 3(6), 305309.

Mulyadi, D., \& Sihabudin, O. S. (2020). Analysis of Current Ratio, Net Profit Margin, and Good Corporate Governance against Company Value. Systematic Reviews in Pharmacy, 11(1), 588-600.

Kasmir. 2008. Analisis Laporan Keuangan. PT. Rajagrafindo Persada 
Prabowo | Quantitative Economics and Management Studies (QEMS), 2020, 1(5): 319-325

Purba, J. H. V., \& Bimantara, D. (2020, May). The Influence of Asset Management on Financial Performance, with Panel Data Analysis. In 2nd International Seminar on Business, Economics, Social Science and Technology (ISBEST 2019) (pp. 150-155). Atlantis Press. 